\title{
Improving Student Communication Skills Through 3D Pageflip E-Book In Education 4.0
}

\author{
Joko Wiharjo ${ }^{1}$, Triana Rejekiningsih ${ }^{2}$, Andre Noevi Rahmanto ${ }^{3}$, \\ The Faculty of Teacher Training and Education, Eleven March Surakarta University Indonesia, J1 \\ Ir. Sutami 36A \\ 1'yohaneskebonan@student.uns.ac.id; ${ }^{2}$ triana_rzqy@ staff.uns, ac.id; ${ }^{3}$ andreyuda@gmail.com
}

\begin{abstract}
Improving students' communication skills through the e-book 3d pageflip of science subjects in the of education 4.0 Purpose This research is to improve students' communication skills through the use of 3D Flippage E-books. This research is a research development. which was held at Tarakanita Solo Baru Junior School in class VII odd semester 2018/2019. In science lessons not only concerns aspects of knowledge but also attitudes and skills. The survey results revealed that the control group gained an average value grade 72 to communicate, while the treatment group obtained the average value of 81 thus using 3D plageflip can enhance critical thinking.
\end{abstract}

Keywords: E-book, critical thinking, education 4.0

\section{INTRODUCTION}

Advancements education is the main trigger for the advancement of human civilization today. Science and technology have encouraged humans to continue to innovate. This progress was marked by the development of the industrial revolution that began from the first industrial revolution until the time of reaching the fourth revolution. The first industrial revolution was born with the invention of the steam engine as a human and animal substitute power. The second industrial revolution was born with the development of the concept of mass production through production machines interchangeable parts that have used electricity. The third industrial revolution was born with the implementation of computer and internet-aided information technology that had an impact on changing fundamental human cultures [1].

At present human civilization in the 21 st century has arrived at the industrial revolution 4.0. The development of massive technological advances is believed to have a very rapid impact on the changing order of the world communication. The presence of smart devices such as smartphones with internet integration offers a wide range of information that is very easily accessed, so that it impacts on changes in human lifestyles, both in socializing, playing and learning [2]. The current internet revolution is not just an information search engine, but more than that, with the internet all can be connected intelligently. All of that is the basis of artificial intelligence that is around us today.

The Industrial Revolution 4.0 also had an impact on the world of education. The conventional learning method with the lecture method in front of the class changes to digital-based learning by utilizing facilities such as Android applications through gadgets, Tabs, cellphones, and other interactive multimedia [3].

Education 4.0 can be a momentum to improve the quality of human resources (HR), including Indonesian HR. In an effort to improve the quality of human resources, it needs support from various aspects of life, one of them is education because it is a very potential aspect in improving the quality of Indonesian human resources, because education is related to the delivery of knowledge and 
values. Thus, education can be understood as an extremely important tool in efforts to improve the quality of Indonesian human resources based on science and technology.

Stages of Education 4.0.

Education 1.0. Education is still carried out in one direction only. Education is still very focused on the teacher as a center of knowledge and material source textbooks.

Education 2.0. The role of education is not entirely on the teacher, but also exchange ideas with students. Broader interaction, can be teachers with students, students with other students and students with experts.

Education 3.0 In 2010 became a new era in the world of education, a new model in learning is applied. The learning process is not only with the teacher but is already collaborative and find out each other. Teachers also come from professionals and people who are experts in their fields. That way the science is more easily directed at students, as well as seeing the child's talent going forward. The most noticeable breakthrough was the birth of a repository that contained digitally educational content that could access it anytime and anywhere. The learning process becomes more flexible and directed according to the wishes of students.

Education 4.0 emphasizes flexibility and creativity. The learning process is not infrequently the fields are carried out remotely. The main concepts applied to Education 4.0 put forward six main things, namely: Various times and places,personalized learning, free choice, project based, field experience, and data interpretation. So that the learning process is successfully applied and in accordance with the changing times

Communication skills are individual skills to convey and receive messages according to context. Communication helps students to articulate ideas and thoughts either verbally, written, or nonverbal in various contexts with the aim that the listener can receive messages appropriately and effectively [3]. Communication is said to be appropriate when students are able to convey messages according to the situation and context being faced. Meanwhile, communication is considered effective if the listener easily understands the contents of the message delivered by the speaker [4]. There are three components that need to be considered by students to achieve appropriate and effective communication. These three components consist of motivation, knowledge, and competence [5].

PageFlip Professional 3D Media is an application software used to make E-Books, Digital Magazines, E-Paper and others. 3D PageFlip Professional is a kind of profession of flip page software for converting PDF files into digital publication page-turning. Each PDF page that is generated can be flipped (back and forth) like a real book. With 3D PageFlip Professional software you can add videos, images, audio, hyperlinks and multimedia objects.

\section{METHOD}

Type of research used is researchand development. Development research is used to produce certain products, and test the effectiveness of these products [6] R\&D as a research method that intentionally, systematically, aims / is directed to searchers find, formulate, improve, develop, produce, test the effectiveness of products, models, methods / strategies / ways, services, certain procedures that are superior, new, effective, efficient, productive and meaningful. [7] [8] [9]

The model used in development is a 4DM model. This model consists of 4 stages of development namely Define, Design, Develop, and Disseminate or adapted into a 4-D model, namely defining, designing, developing, and spreading. [6] [10] 


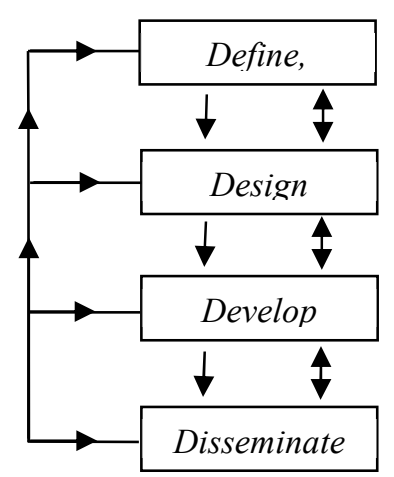

Figure 1. 4D Model

\section{RESULT AND DISCUSSION}

From the background of the above problems can be formulated; Can the 3D Pageflip E-book improve students' communication skills?

From observations at Tarakanita Junior High School Solo Baru show that students have sufficient intellectual intelligence abilities in terms of their learning still needs to be improved by the process of critical thinking and collaboration in teams.

Science is a very interesting science, in which there are objects, problems, methods, and scientific products. Objects in natural science include all objects in the universe. Natural science problems in this case include the phenomenon of natural events and events. The method in IPA refers to the scientific method and scientific process, while scientific products are in the form of scientific facts, scientific concepts, basic principles of scientific theory and scientific law. In Science Education using a variety of approaches, the K-13 often uses a scientific approach. By using an approach in studying science, it will form attitudes and characters such as honest, open, critical, responsibility, curiosity, collaboration, communication.

The following data are from the Smt-1 IPA scores for Tarakanita Junior High School in Solo Baru

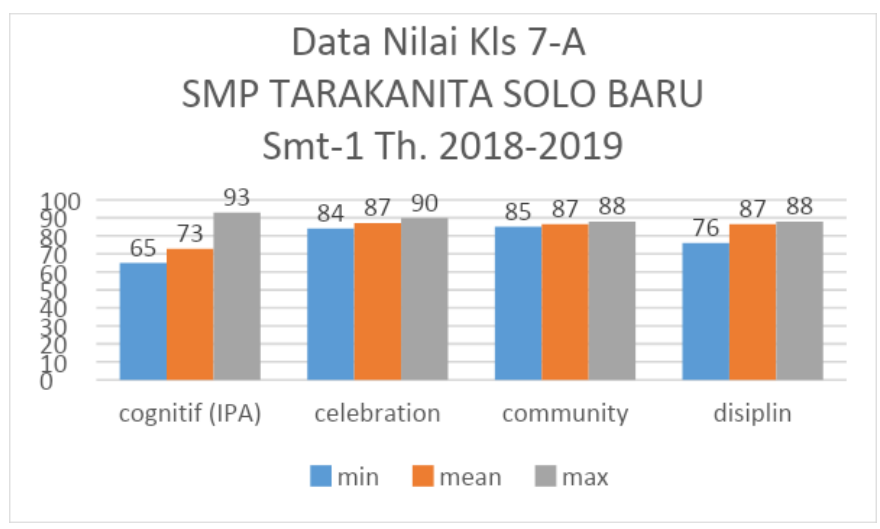

Figure 2. Recap of the IPA values and first semester attitudes

Thevalues cognitive above are values collected from all assessments starting from the daily, midterm and midterm semester 2018-2019 scores. As for the value of celebration, community, and discipline. Celebration is an attitude of humility that all life events are never separated from God's intervention, each student is expected to be able to interpret every event in life with gratitude. 
Community is one's ability to develop true brotherhood and equality, diversity is not a division, but enriches one another. Discipline is obedience to the rules, applicable provisions. But discipline is not a superficial attitude that is just to obey the rules and follow the rules that apply, but a sincere attitude because there are goals to be achieved [11].

For this reason, the learning process requires learning methods, approaches, learning strategies and teaching materials that are in accordance with current learning needs. E-book, one of the answers to equip students to have 21 st century skills [12] [13].[14]With the E-book, the subject matter can be easily accessed anywhere and anytime, because every student has a tool to access it.

The learning process at Tarakanita Junior High School Solo Baru has implemented 21st century skills by applying character education in each of its learning, but for the use of books it is still conventional, still using printed books. Not using digital books.

From the observations it appears that science learning with a scientific approach has an impact on strengthening student behavior ; Celebration with an average rating of 87 , a community with an average of 87 , and discipline of 87 . This shows that students have gratitude, and good sense of discipline and discipline.

\subsection{Celebration}

Celebration has aspects, students are able to understand and live an attitude of gratitude, steadfast, empowered in achieving success and the spirit of ugahari in achieving success in life in the environment. Indicators:

a. Identify strengths and weaknessesself

b. Formulate-development efforts based on identification results

c. Apply self-development efforts: persevering, persevering, full of fighting power

d. Formulating understanding of the spirit of ugahari

e. Mentioning the challenges that exist in the surrounding environment in achieving ugahari

f. spirit Applying ugahari spirit in life Everyday

\subsection{Community}

Community has aspects, Students are able to show the attitude of living together in building true brotherhood in the school, family and community environment. In the community there are values of the Collaborator Idicator:

a. Participate actively in carrying out attitudes to build true brotherhood in the school, family, and community environment.

b. Evaluate life experiences in building true brotherhood in the school, family, and community circles.

c. Reflecting life experiences in building True brotherhood in the school environment, family, and in thecommunity

\subsection{Disciplinaryhas aspects}

Disciplinaryhas aspects, students are able to build discipline as a means of realizing order and success in life. The indicators:

1. Reflecting the behaviors of discipline and discipline in our homes, schools, and communities

2. Noting the successes and obstacles when adhere to the rules made themselves communicate ndicators. 
Table 2. Indicators communicate

\begin{tabular}{|l|l|}
\hline \multirow{2}{*}{ Communication Skill } & \multicolumn{1}{|c|}{ Indicators } \\
\cline { 2 - 2 } & Reading \\
\cline { 2 - 2 } & Writing \\
\cline { 2 - 2 } & Listening \\
\cline { 2 - 2 } & Speaking \\
\hline
\end{tabular}

Table 3. Communication rubric [12]

\begin{tabular}{|c|c|c|c|c|}
\hline \multirow{2}{*}{ CRITERIA } & \multicolumn{4}{|c|}{ SCORING } \\
\hline & 4 & 3 & 2 & 1 \\
\hline $\begin{array}{l}\text { Reading } \\
\text { 1. Read more than one reference } \\
\text { 2. Find the main idea } \\
\text { 3. Express the content of the idea } \\
\text { 4. Convey the idea }\end{array}$ & $\begin{array}{l}\text { Meet four } \\
\text { (4) } \\
\text { criteria }\end{array}$ & $\begin{array}{l}\text { Meet three } \\
\text { (3) criteria }\end{array}$ & $\begin{array}{l}\text { Meet two } \\
\text { (2) criteria }\end{array}$ & $\begin{array}{l}\text { Meet one (1) or } \\
\text { do not meet all } \\
\text { the criteria }\end{array}$ \\
\hline $\begin{array}{l}\text { Writing } \\
\text { 1. Pouring ideas } \\
\text { 2. Expressing ideas through types of } \\
\text { writing (narration, description, } \\
\text { argumentation, exposition, persuasion) } \\
\text { 3. Using the language order } \\
\text { (according to EYD) } \\
\text { 4. Choosing the right diction / words }\end{array}$ & $\begin{array}{l}\text { Meet four } \\
\text { (4) criteria }\end{array}$ & $\begin{array}{l}\text { Meet three } \\
\text { (3) criteria }\end{array}$ & $\begin{array}{l}\text { Meet two } \\
\text { (2) Criteria }\end{array}$ & $\begin{array}{l}\text { Meets one (1) or } \\
\text { does not meet } \\
\text { allcriteria }\end{array}$ \\
\hline $\begin{array}{l}\text { Hearing } \\
\text { 1. Responds well } \\
\text { 2. Repeats } \\
\text { 3. Interprets }\end{array}$ & $\begin{array}{l}\text { Meets three } \\
\text { (3) criteria }\end{array}$ & $\begin{array}{l}\text { Meets two } \\
\text { (2) criteria }\end{array}$ & $\begin{array}{l}\text { Meets one } \\
\text { (1) criterion }\end{array}$ & $\begin{array}{l}\text { Does not meet all } \\
\text { the criteria }\end{array}$ \\
\hline $\begin{array}{l}\text { Speaking } \\
\text { 1. Chooses the correct diction / word } \\
\text { 2. Accuracy intonation: meek } \\
\text { pronunciation of a word (articulation) } \\
\text { 3. Smoothness }\end{array}$ & $\begin{array}{l}\text { Meets four } \\
\text { (4) criteria }\end{array}$ & $\begin{array}{l}\text { Meets three } \\
\text { (3) criteria }\end{array}$ & $\begin{array}{l}\text { Meets two } \\
\text { (2) criteria }\end{array}$ & $\begin{array}{l}\text { Meets one (1) or } \\
\text { does not meet all } \\
\text { the criteria }\end{array}$ \\
\hline
\end{tabular}

From the rubric results obtained value of the control class (using textbooks) indicators asking for a score of 72 while for the treatment group (using $3 \mathrm{~d}$ flip) obtaining a score of 81

\section{CONCLUSION}

Based on the learning outcomes data that has been done, it can be concluded that learning science by using a 3D pageflip E-book can improve the communication skills of students of class VII Tarakanita Junior School. 


\section{REFERENSCES}

[1] W. Ekatjahjana, "Kemendiknas," 2010.

[2] M. Agustina, "Pemanfaatan E-Learning sebagai Media Pembelajaran," Seminar Nasional Aplikasi Teknologi dan Informasi (SNATI), 2013. .

[3] Depdiknas, "Panduan Penilaian Kelompok Mata Pelajaran Ilmu Pengetahuan dan Teknologi," Jakarta: BNSP, 2006.

[4] M. Morreale, S., Staley, C., Stavrositu, C., \& Krakowiak, "First year college students' attitudes toward communication technologies and their perceptions of communication competence in the 21st century.," Commun. Educ., 2014.

[5] N. . et all Lederman, "View of Nature of Science Questionnaire: Toward Valid and meaningful Assesment of Learns' Conception of Nature Science," J. reserch Sci. Teach., 2002.

[6] H. Sugiyanto, Model-Model Pembelajaran Inovatif. Surakarta: Yama Pustaka, 2009.

[7] A. Suharsimi, Research Procedure A Practical Approach. jakarta: Rineka Cipta, 2006.

[8] B. W. R. \& Dall Meredith D, Educational Research. London: Longman Inc, 1983.

[9] W. Dick, "A model for the systematic design of instruction," Instr. Des. Int. Perspect. Theory, Res. Model., vol. 1, pp. 361-370, 2013.

[10] D. S. S. dan M. I. S. S. Thiagarajan, Instructional Development for Training Teachers of Exceptional Children: A Sourcebook. Washington, D. C: National Center for Improvement of Educational Systems DHEW/OE, 1974.

[11] Eto ad all, Tarakanita CC5 +Curriculum Book. Jakarta: Divisi Pendidikan Yayasan Tarakanita, 2015.

[12] Rusman, Belajar dan Pembelajaran Berbasis Komputer MengembangkanProfesionalisme Guru Abad 21. Bandung: Alfabeta, 2013.

[13] A. Susanto, Teori Belajar dan Pembelajaran di Sekolah Dasar. Jakarta: Kencana Prenada Media Group, 2013.

[14] Setyorini, R., Saddhono, K., Ermanto, Wildan, M., Kirom, S. The Effort of Implementing of the Big Book as A Media to Improve the Intelligence of Linguistic Verbals for Early Childhood. Journal of Physics: Conference Series 1339(1),012087 